Edyta Kosik Instytut Bibliotekoznawstwa i Informacii Naukowej Uniwersytet Śląski w Katowicach email: edyta.kosik90@gmail.com

\title{
Bibliofil w Internecie, czyli grupy poświęcone tematyce książek w serwisie Facebook
}

STRESZCZENIE: Internet oferuje obecnie miłośnikom książek nowe możliwości komunikacji i integracji - dając im perspektywę stworzenia społeczności skupionej wokół ich pasji. Artykuł charakteryzuje konkretny typ tych społeczności - grupy poświęcone tematyce książek w serwisie Facebook. W artykule przedstawiono definicję mediów społecznościowych i e-społeczności. Omówiono i scharakteryzowano serwis internetowy Facebook. Następnie przedstawiono jeden ze sposobów komunikacji miłośników książek w serwisie - grupy poświęcone tematyce książek. Na podstawie analizy 47 grup omówiono ich strukturę (liczebność, dostęp do nich i aktywność ich uczestników) oraz prezentowane w nich informacje. Zwrócono uwagę, które z tych informacji są najbardziej istotne dla ich uczestników. Na podstawie przeprowadzonych badań ankietowych scharakteryzowano także uczestników grup poświęconych tematyce książek. Wykazano, jakie elementy tych społeczności najbardziej cenią ich uczestnicy, a które uważają za wady oraz co skłoniło ich do przystąpienia do nich.

SŁoWA KLUCzowE: e-społeczności, Facebook, grupy, Internet, książka, serwis społecznościowy.

\section{Wprowadzenie}

nternet stwarza obecnie miłośnikom książek nowe możliwości komunikacji. Niezależnie od miejsca zamieszkania mogą oni dzielić się swoimi 
przemyśleniami na temat przeczytanych książek, pisać recenzje, informować o nowych tytułach czy zapowiedziach wydawniczych. Miejscem idealnym do tego, aby miłośnicy słowa pisanego komunikowali się między sobą, dzieląc się swoją pasją, są media społecznościowe.

Media społecznościowe są definiowane jako

zbiór relacji, zachowań, uczuć, interakcji pomiędzy użytkownikami, gdzie następuje wielokierunkowa komunikacja wymiany doświadczeń za pomocą zaawansowanych narzędzi komunikacji ${ }^{1}$.

Termin ten można też rozumieć jako

zbiór technologii do inicjowania i przekazu treści między ludźmi, ich znajomymi i sieciami społecznościowymi, do których należą².

Wśród cech, jakimi charakteryzują się media społecznościowe, można wymienić:

- dowolną skalę ich wykorzystywania przez odbiorców,

- możliwość wielokrotnej zmiany informacji pierwotnej,

- wolność w tworzeniu i dostępie do treści,

- stały dostęp do informacji, które są wynikiem pracy twórczej jej autorów,

- rozpowszechnianie treści poprzez społeczną interakcję,

- tworzenie treści w sposób niewymuszony,

- publikacja treści w bardzo krótkim odstępie czasu od jej wytworzenia,

- użytkownicy mediów są jednocześnie odbiorcami i twórcami danej treści serwisu ${ }^{3}$.

Obecnie jednym z najpopularniejszych serwisów społecznościowych jest Facebook. Projekt tego serwisu powstał w lutym 2004 r. na

1 J. Przybysz, P. Pioterek, Media społecznościowe w służbie bibliotek, [w:] Biblioteki bez użytkowników? Diagnoza problemu. V Ogólnopolska Konferencja Naukowa Supraśl 14-16 września 2015, pod red. J. Żochowskiej, Białystok 2015, s. 341-342.

2 P. Milc, Media społecznościowe jako forma komunikacji bibliotek z czytelnikiem na przykładzie portalu Facebook, [w:] Bibliotekarz 2.0. Nowe technologie, nowe wyzwania, pod red. S. Skórki, M. Rogoża, E. Piotrowskiej, Kraków 2016, s. 36.

3 J. Przybysz, P. Pioterek, dz. cyt., s. 341-342. 
Uniwersytecie Harvarda, a jego twórcą jest Mark Zuckerberg. W Polsce portal rozpoczął działalność w 2008 r. dzięki umieszczeniu go na portalu Grom ${ }^{4}$. Na początku przeznaczony był dla uczniów i studentów w celu kontynuacji kontaktów szkolnych, wymiany informacji i zdjęć. $\mathrm{Z}$ biegiem czasu stał się jednak narzędziem komunikacji, dziś jednym z najpopularniejszych (w 2012 r. liczba jego użytkowników wynosiła 1 miliard) $)^{5}$. Obecnie Facebook oferuje wiele możliwości, m.in. tworzenie własnej strony (ang. fanpage), dzielenie się wiadomościami, zdjęciami, korzystanie z aplikacji, publikowanie wydarzeń z życia użytkowników na osi czasu oraz zakładanie grup. Ostatnia z wymienionych funkcji jest przedmiotem niniejszego artykułu. Autorka podjęła w nim próbę scharakteryzowania facebookowych grup o tematyce książek, zarówno pod względem ich zawartości, jak i skupionych wokół nich społeczności. Analizom podano 47 grup wybranych w sposób losowy spośród wielu znajdujących się w serwisie. Ponadto przeprowadzono badania ankietowe wśród ich członków, na które odpowiedziało 485 (ankieta nr 1) i 447 (ankieta nr 2) respondentów. Sugestie członków grup o książkach głoszone w toku prowadzonego badania (ankieta nr 1) skłoniły autorkę do przeprowadzenia drugiej ankiety z pytaniami uzupełniającymi (ankieta nr 2). Oba badania przeprowadzono pośród członków tych samych 47 analizowanych grup. Badania ankietowe odbyły się między 31 października 2016 a 13 marca 2017 r. i były prowadzone w formie elektronicznej. Respondentów wybrano w sposób losowy. Formularze ankiet dodano w załącznikach nr 1 i 2.

\section{Ksiqzika na Facebooku}

Na Facebooku wśród wielu treści można odnotować także te związane z książką, jej miłośnikami i wydarzeniami z nią związanymi. Swoje fanpage'e w serwisie mają wydawnictwa, strony poświęcone książkom (Lubimy Czytać czy BiblioNETka), blogerzy i wszyscy miłośnicy książek. Zakła-

${ }^{4}$ P. Milc, dz. cyt., s. 37.

${ }^{5}$ H. Klepacz, A. Usielska, Facebook jako konsekwencja ewolucji w komunikacji społecznej, [w:] Media i dziennikarstwo w XX wieku. Studia i szkice, pod red. M. Kaczmarczyka i M. Boczkowskiej, Sosnowiec 2015, s. 161-164. 
dane są także liczne grupy skupiające wokół książek osoby, których pasją jest czytanie. Na Facebooku osoby związane z książką oraz jej miłośnicy promują swoją działalność, a także propagują czytelnictwo, dyskutują o książkach, publikują opinie i recenzje.

Grupy o książkach na Facebooku są jednym z przykładów e-społeczności, które można definiować jako

grupę ludzi, którzy odbywają interakcje w środowisku wirtualnym. Mają oni cel, opierają się na technologii i kierują się normami i przepisami $^{6}$

a także jako

zbiorowość użytkowników Internetu, którzy w aktywny sposób wykorzystują tę platformę komunikacji do wymiany informacji i komunikatów związanych z ich wspólnymi zainteresowaniami, przekonaniami i postawami ${ }^{7}$.

Analizowane grupy poświęcone tematyce książek w serwisie Facebook są zróżnicowane pod względem liczby członków, ich aktywności i podejmowanej tematyki. Liczba członków grup rozpięta jest pomiędzy 30 tys. (grupy duże), 2 tys. (grupy średnie) a 80 (grupy małe). Aktywność uczestników w większości grup (58\%) jest bardzo duża i duża posty na tablicach grup pojawiają się co kilka godzin lub dni i są licznie komentowane. W 13\% grup można zaobserwować średnią aktywność członków - posty pojawiają się co kilkanaście dni i na ogół wzbudzają reakcje w postaci komentarzy. Małą aktywność członków lub brak tej aktywności odnotowuje się z kolei dla $17 \%$ grup - posty publikowane są na ogół kilka razy na rok i brak reakcji na nie lub posty całkowicie przestały się pojawiać. Można wyróżnić dwa rodzaje grup o książkach zamknięte (do których informacji dostępu nie mają wszyscy użytkownicy Facebooka, tylko ich członkowie) i otwarte (informacje zamieszczane w grupach są dostępne dla wszystkich użytkowników portalu). Tabela 1 obrazuje liczebność grup i aktywność ich członków oraz dostęp do nich.

6 W. Gustowski, Komunikacja w mediach społecznościowych, Gdynia 2012, s. 93-94.

7 Tamże, s. 95. 
Tabela 1. Grupy o książkach - liczebność, aktywność członków i status

\begin{tabular}{|c|c|c|c|c|c|}
\hline \multirow[t]{2}{*}{ Lp. } & \multirow[t]{2}{*}{ Nazwa } & \multirow{2}{*}{$\begin{array}{c}\text { Liczba } \\
\text { członków }\end{array}$} & \multirow{2}{*}{$\begin{array}{c}\text { Aktywność } \\
\text { członków grupy }\end{array}$} & \multicolumn{2}{|c|}{ Status grupy } \\
\hline & & & & zamknięta & otwarta \\
\hline 1 & $\begin{array}{c}\text { AK - } \\
\text { Klub (nie) Anonimowych } \\
\text { Książkoholików }\end{array}$ & 36436 & bardzo duża & $\mathrm{x}$ & \\
\hline 2 & $\begin{array}{c}\text { Nie mam czasu, czytam } \\
\text { książki }\end{array}$ & 25516 & bardzo duża & & $\mathrm{x}$ \\
\hline 3 & Z jakiej to książki? & 13061 & bardzo duża & $\mathrm{x}$ & \\
\hline 4 & KSIĄŻKI & 6954 & bardzo duża & & $\mathrm{x}$ \\
\hline 5 & $\begin{array}{c}\text { Lubię czytać książki. } \\
\text { Należę do ginącego } \\
\text { gatunku. }\end{array}$ & 6724 & bardzo duża/duża & & $\mathrm{x}$ \\
\hline 6 & Dobra Książka & 6623 & duża & $\mathrm{x}$ & \\
\hline 7 & Czytamy polskich autorów & 6552 & bardzo duża & & $\mathrm{x}$ \\
\hline 8 & $\begin{array}{l}\text { Nie jestem statystycznym } \\
\text { Polakiem, czytam więcej } \\
\text { niż jedną książkę rocznie }\end{array}$ & 6523 & bardzo duża & $\mathrm{x}$ & \\
\hline 9 & Zaczytani & 5575 & bardzo duża & & $\mathrm{x}$ \\
\hline 10 & Książka tygodnia & 2765 & bardzo duża/duża & & $\mathrm{x}$ \\
\hline 11 & Czytanie ma branie. & 2692 & bardzo duża/duża & & $\mathrm{x}$ \\
\hline 12 & Blogosfera książkowa & 2034 & bardzo duża/duża & $\mathrm{x}$ & \\
\hline 13 & Dyskusyjny Klub Książki & 1876 & duża & & $\mathrm{x}$ \\
\hline 14 & Klub czytelników & 1830 & duża & $\mathrm{x}$ & \\
\hline 15 & Czytamy bo kochamy & 1820 & bardzo duża/duża & $\mathrm{x}$ & \\
\hline 16 & Kocham książki & 1795 & duża & $\mathrm{x}$ & \\
\hline 17 & Czytające kobiety :) & 1377 & bardzo duża/duża & $\mathrm{x}$ & \\
\hline 18 & $\begin{array}{l}\text { Nie jesteśmy frajerami! } \\
\text { Czytamy książki! }\end{array}$ & 1277 & bardzo duża & & $\mathrm{x}$ \\
\hline 19 & $\begin{array}{c}\text { Książkoświrki - recenzje, } \\
\text { wymianki, sobotnie stosy } \\
\text { i takie tam) }\end{array}$ & 1249 & bardzo duża & $\mathrm{x}$ & \\
\hline 20 & Lubimy czytać książki & 1080 & bardzo duża/duża & & $\mathrm{x}$ \\
\hline 21 & $\begin{array}{l}\text { Czytający w pracy } \\
\text { i nocami }\end{array}$ & 818 & bardzo duża/duża & $\mathrm{x}$ & \\
\hline
\end{tabular}


Tabela 1. Grupy o książkach (cd.)

\begin{tabular}{|c|c|c|c|c|c|}
\hline \multirow[t]{2}{*}{ Lp. } & \multirow[t]{2}{*}{ Nazwa } & \multirow{2}{*}{$\begin{array}{c}\text { Liczba } \\
\text { członków }\end{array}$} & \multirow{2}{*}{$\begin{array}{c}\text { Aktywność } \\
\text { członków grupy }\end{array}$} & \multicolumn{2}{|c|}{ Status grupy } \\
\hline & & & & zamknięta & otwarta \\
\hline 22 & Czytanie to wyzwanie & 729 & duża & $\mathrm{x}$ & \\
\hline 23 & Książkowa Kawiarenka & 704 & średnia & $\mathrm{x}$ & \\
\hline 24 & Szukam książki... & 646 & średnia & & $\mathrm{x}$ \\
\hline 25 & Czytamy kryminały & 640 & duża & $\mathrm{x}$ & \\
\hline 26 & Blogi książkowe & 601 & bardzo duża & $\mathrm{x}$ & \\
\hline 27 & Rozmowy o książkach & 575 & średnia & $\mathrm{x}$ & \\
\hline 28 & Mole Książkowe & 535 & średnia & $\mathrm{x}$ & \\
\hline 29 & Książki są fajne i kropka! & 489 & średnia & $\mathrm{x}$ & \\
\hline 30 & Blogi książkowe :) & 393 & bardzo duża/duża & $\mathrm{x}$ & \\
\hline 31 & Klub kochających książki! & 339 & średnia & $\mathrm{x}$ & \\
\hline 32 & $\begin{array}{l}\text { Bibliotekarze i miłośnicy } \\
\text { książki }\end{array}$ & 337 & średnia & & $\mathrm{x}$ \\
\hline 33 & Blogerzy Książkowi & 307 & bardzo duża/duża & & \\
\hline 34 & KSIĄŻKI KSIĄŻKI & 303 & bardzo mała & & $\mathrm{x}$ \\
\hline 35 & Piszemy o książkach & 303 & duża/średnia & & $\mathrm{x}$ \\
\hline 36 & $\begin{array}{l}\text { Porozmawiajmy } \\
\text { o książkach }\end{array}$ & 287 & bardzo duża & & $\mathrm{x}$ \\
\hline 37 & $\begin{array}{l}\text { Klub Recenzenta } \\
\text { Książkowego }\end{array}$ & 237 & duża & $\mathrm{x}$ & \\
\hline 38 & książki & 131 & bardzo mała & & $\mathrm{x}$ \\
\hline 39 & Ksiazki Ktore Kocham & 111 & średnia & $\mathrm{x}$ & \\
\hline 40 & CZYTAM KSIĄŻKI & 109 & mała & & $\mathrm{x}$ \\
\hline 41 & Klub Miłośników Książek & 95 & bardzo mała & $\mathrm{x}$ & \\
\hline 42 & CzytajMy & 80 & brak & & $\mathrm{x}$ \\
\hline 43 & lubiący czytać & 65 & brak & & $\mathrm{x}$ \\
\hline 44 & Mole książkowe & 45 & bardzo mała & $\mathrm{x}$ & \\
\hline 45 & $\begin{array}{l}\text { Fani książek! Czytamy } \\
\text { ile się da! }\end{array}$ & 36 & bardzo mała & $\mathrm{x}$ & \\
\hline 46 & Mole Książkowe & 32 & średnia & $\mathrm{x}$ & \\
\hline 47 & Czytamy Książki & 23 & bardzo mała & & $\mathrm{x}$ \\
\hline
\end{tabular}

Źródło: opracowanie własne. 
Tematyka analizowanych grup jest na ogół związana z książką w ogóle, ale można także zauważyć grupy poruszające jeden aspekt związany z czytaniem - skupiające się wokół miłośników jednego typu literatury (np. kryminałów czy literatury polskiej), samych tylko blogerów lub recenzentów książek, czy też wokół samych kobiet czytających. Informacje, jakie pojawiają się w grupach o książkach, są różnorodne (por. wykres 1). Rodzaje informacji, jakie prezentowane są w grupach o książkach, zostały ustalone na podstawie analizy tablic 47 grup o tematyce książkowej badanych na potrzeby niniejszego tekstu.

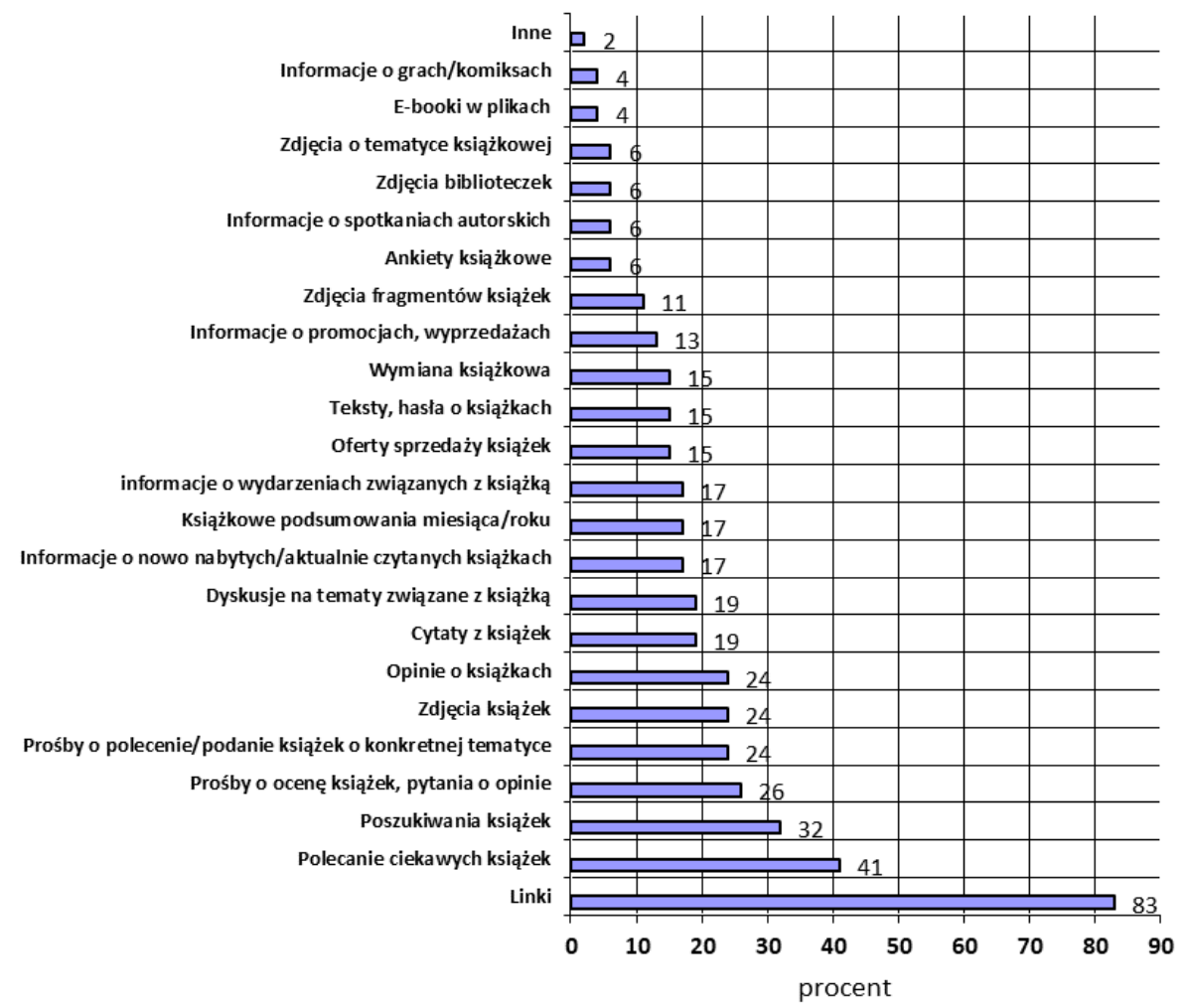

Wykres 1. Rodzaje informacji prezentowanych w grupach o książkach

Źródło: opracowanie własne.

W większości grup (83\%) publikowane są odsyłacze do różnych informacji związanych z książką (recenzji, blogów, konkursów, premier, 
zapowiedzi wydawniczych, profili o książkach, wydarzeń związanych z czytaniem, wywiadów, czatów z autorami, promocji książkowych, czasopism bibliotecznych, e-booków czy stron autorów). Członkowie dużej części grup (41\%) polecają sobie także ciekawe, warte przeczytania książki. W dużej liczbie społeczności grupowych (32\%) ich członkowie poszukują książek, których tytułu nie znają. W wielu grupach użytkownicy proszą społeczność o wyrażenie opinii na temat konkretnych książek (26\%) oraz o polecenie książek o konkretnej tematyce (24\%). Można zauważyć też grupy, w których zamieszczane są zdjęcia książek (24\%), opinie o przeczytanych tytułach (21\%) i cytaty (19\%). W 19\% spośród analizowanych grup ich członkowie dyskutują na tematy książkowe i okołoksiążkowe. W grupach zamieszczane są także podsumowania miesiąca lub roku (17\% grup), oferty sprzedaży książek, teksty lub hasła o książkach, informacje o wymianie książkowej (15\% grup), informacje o promocjach i wyprzedażach (13\% grup), zdjęcia fragmentów książek (11\% grup), ankiety na temat książek, informacje o spotkaniach autorskich, zdjęcia biblioteczek użytkowników, zdjęcia o tematyce książkowej (6\% grup), e-booki w plikach, informacje o grach lub komiksach (4\% grup) oraz inne informacje (2\% grup).

Jak wykazały badania ankietowe przeprowadzone przez autorkę, prezentowane $\mathrm{w}$ grupach różnego typu informacje mają zróżnicowane znaczenie dla uczestników grup. Najważniejsze jest dla nich polecanie tytułów książek przez innych członków grupy. Istotne są także takie elementy, jak: możliwość prowadzenia dyskusji o książkach, recenzje książek prezentowane w grupach, linki kierujące do ciekawych pozycji książkowych, wskazówki, czy zakupione książki są warte czytania. Mniej ważne są następujące informacje prezentowane w społecznościach grup o książkach: informacje o kiermaszach lub tanich książkach, cytaty z książek oraz prezentowanie przez innych grupowiczów swoich zdobyczy książkowych. Znaczenia nie mają z kolei linki do blogów książkowych, zdjęcia bliblioteczek innych członków grupy, a także zdjęcia fragmentów książek.

Członkami grup o książkach są głównie kobiety (92\% badanych), osoby w przedziale wiekowym od 20-23 lat (58\% badanych), o wykształceniu średnim i wyższym (kolejno 35\% i 49\% badanych). Są oni czytelnikami intensywnymi, tzn. czytają siedem i więcej książek w ciągu roku. W większości przypadków liczba czytanych książek zdecydowanie przekracza siedem (mieści się w przedziale 50-250 książek). 
Członkowie grup o tematyce książkowej dowiedzieli się o nich w różny sposób (por. wykres 2). Zostali zaproszeni przez znajomych (15\% badanych) lub znajomi polecili im konkretne grupy ( $8 \%$ badanych). Duża liczba badanych przeglądała grupy w serwisie Facebook w celu odnalezienia grup poświęconych książkom (40\% badanych). Najwięcej odpowiadających dołączyło do grup o książkach, ponieważ wyświetliły się one im wśród grup proponowanych przez portal (49\% badanych). 4\% badanych wymieniło inne sposoby, poprzez które dowiedzieli się o grupach poświęconych książkom - większość z nich stwierdziła, że sama założyła takie grupy.

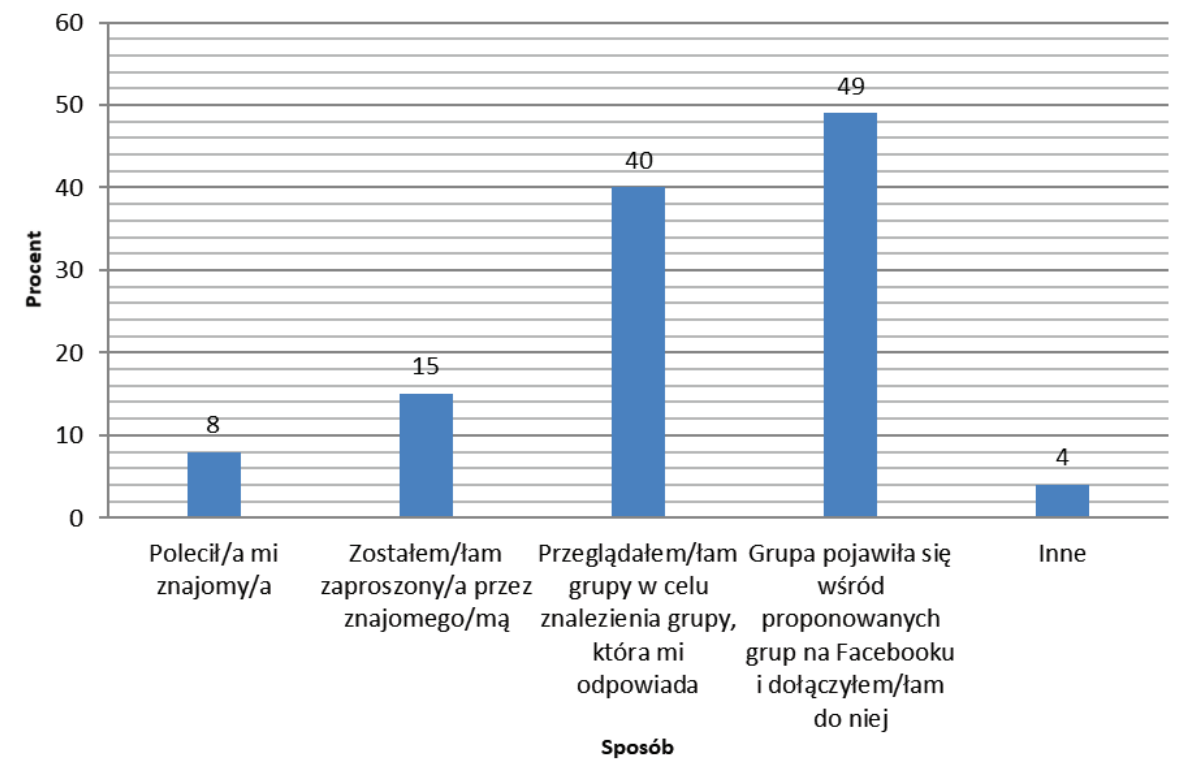

Wykres 2. Sposoby, w jaki członkowie grup poświęconych książkom dowiedzieli się o ich istnieniu

Źródło: opracowanie własne.

Członkowie grup o książkach, które brały udział w badaniach ankietowych, zwykle należą do kilku grup o tej tematyce (od 2 do 30 grup). Osoby te są na różne sposoby związane ze światem książek (por. wykres 3) - są księgarzami (2\%), bibliotekarzami (3\%), blogerami książkowymi (12\%), recenzentami książek (9\%), wydawcami (2\%), pisarzami (8\%) lub po 
prostu czytelnikami książek (90\%). Uczestnicy tych społeczności są zarówno ich biernymi użytkownikami (49\% badanych) - nie publikują i nie komentują postów, jak i aktywnymi (51\% badanych) - publikują posty i je komentują.

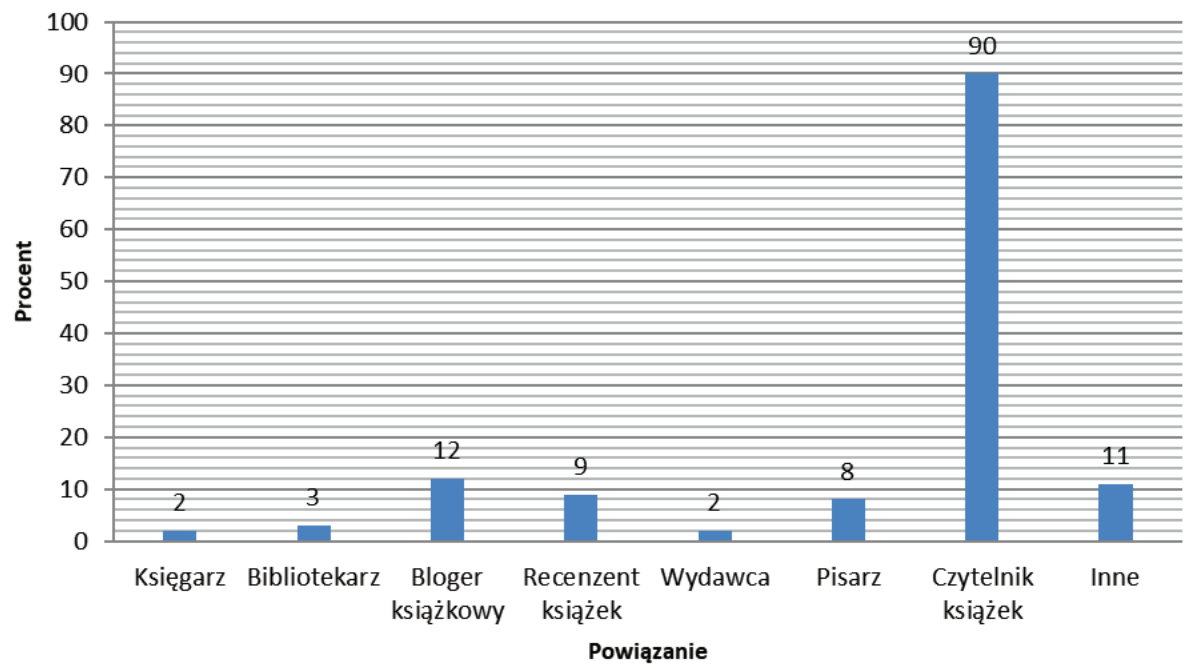

Wykres 3. Sposób powiązania uczestników grup poświęconych książkom ze światem książek

Źródło: opracowanie własne.

Okres uczestnictwa respondentów w grupach poświęconych książkom jest zróżnicowany - najkrótszy to kilka dni, a najdłuższy cztery lata. O przystąpieniu do społeczności grup o książkach przez ich użytkowników decydują różne powody (por. wykres 4): w największym stopniu (38\%) - chęć poznania nowych lub ciekawych książek, w drugiej kolejności - dyskusje prowadzone w tych grupach (14\%), tj. o książkach i na tematy okołoksiążkowe (np. o wydarzeniach z książką związanych). Dużą grupą uczestników książkowych społeczności (12\%) kieruje także chęć poznania osób o takich samych upodobaniach związanych z książką oraz kontaktu z tymi. Hobby, czyli miłość do książek, skłania 10\% ankietowanych do przystąpienia do grup o książkach. 8 \% badanych wskazuje jako powód przyłączenia się do społeczności ciekawość, dla 5\% badanych ważnym powodem uczestnictwa są recenzje w nich prezentowane, 3\% 
badanych natomiast wyznaje, że powodowała nimi chęć bycia na bieżąco z wydarzeniami związanymi z książką, dowiedzenia się, jakie pozycje czytają inni, oraz możliwość uczestnictwa w społecznościach. Inne powody to (1\%): prezentowanie swoich ofert sprzedaży książek lub poszukiwanie ofert innych, poszerzanie horyzontów czytelniczych, polecenie przez znajomych, promocje książkowe, nuda oraz promocja bloga.

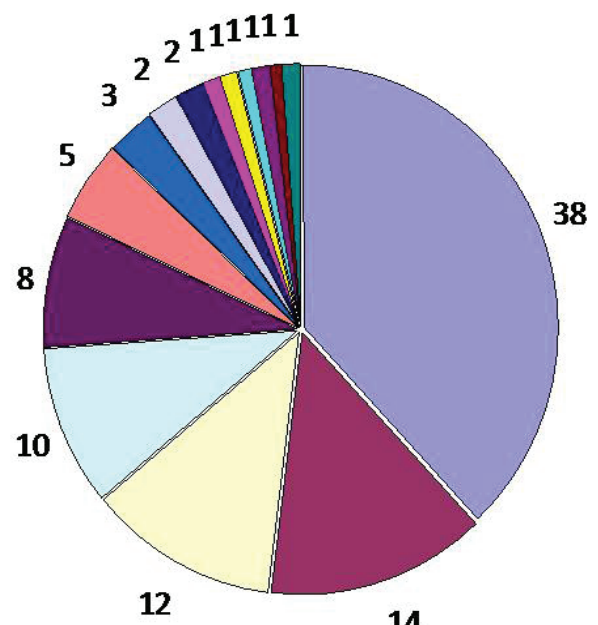

14

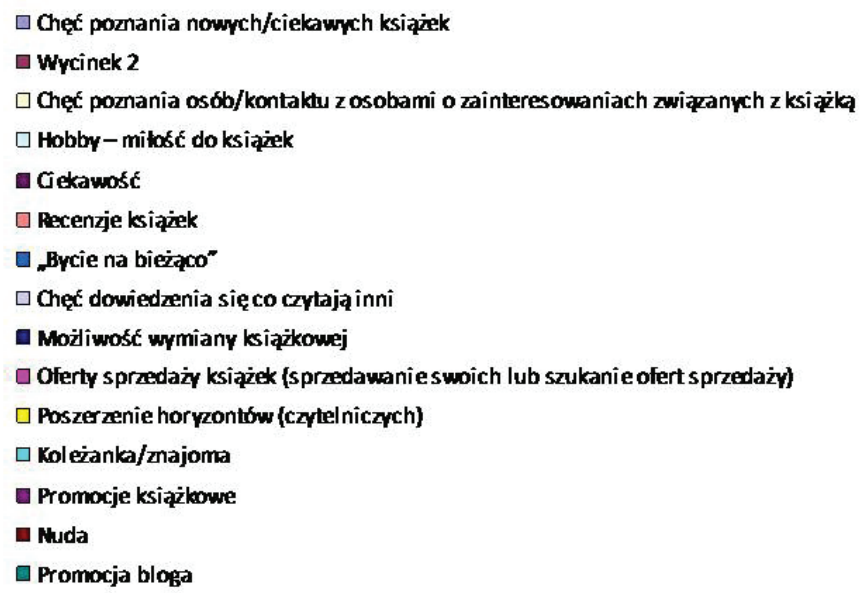

Wykres 4. Powody uczestnictwa w grupach o książkach (udział procentowy) Źródło: opracowanie własne. 
Badani uczestnicy grup o książkach czytali w większości (97\%) „od zawsze", tylko 3\% z nich zaczęło czytać po przystąpieniu do społeczności. W większości (58\%) nie zauważyli oni także, że zaczęli więcej czytać w wyniku członkostwa w grupach. Stwierdzili natomiast, że wielu ciekawych pozycji i wydarzeń związanych z książką (kolejno 81\% i 69\% badanych) nie poznaliby, gdyby nie byli członkami grup. Uczestnicy grup o książkach w większości (89\%) są zadowoleni z wyborów książkowych dokonywanych pod wpływem innych członków.

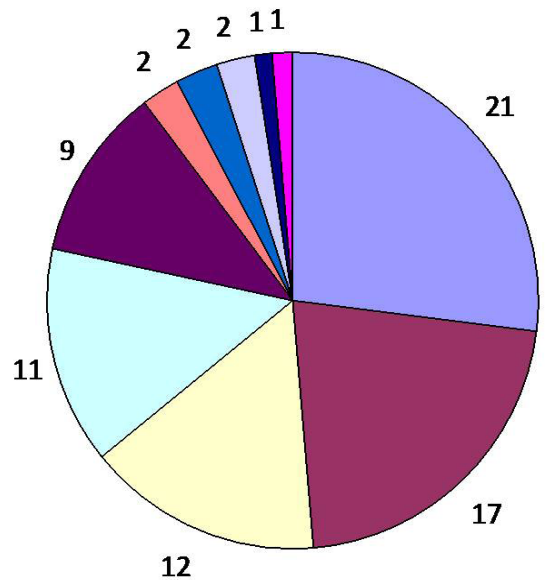

口Poznawanie nowych tytułów (polecanych przez członków, o których informuja członkowie)

口Opinie o książkach (poznawanie i dzielenie się nimi)

口Ludzie o podobnych zaintere sowaniach (poznawanie i rozmowa z nimi, źródło inspiracji)

口Dyskusje o książkach i na tematy okołoksiążkowe

口Recenzje książek

口Dzielenie się wiedzą, pasją

aCytaty

口Atmosfera

Donkursy

口Informacje o promocjach książkowych

Wykres 5. Zalety uczestnictwa w grupach o książkach (udział procentowy) Źródło: opracowanie własne.

Jako zalety uczestnictwa w grupach (por. wykres 5) o książkach ankietowani w pierwszej kolejności (21\%) wskazali poznawanie nowych tytułów (polecanych przez członków czy też tych, o których informują). Kolejną zaletą są opinie o książkach (17\%) - zarówno poznawanie ich, jak i dzielenie się nimi. Plusem uczestnictwa w grupach o książkach jest według $12 \%$ badanych poznawanie i rozmowa z ludźmi o podobnych zainteresowaniach, którzy często są źródłem inspiracji dla uczestników grup. Ankietowanym podobają się także (11\%) dyskusje o książkach i na tematy okołoksiążkowe. Dla $9 \%$ badanych zaletą uczestnictwa w grupach jest możliwość przeglądania recenzji książek. Dla $2 \%$ respondentów plusem są takie elementy, jak: dzielenie się wiedzą i pasją, cytaty z książek 
czy atmosfera panująca w grupach. Z kolei dla $1 \%$ badanych zaletą uczestnictwa w grupach są konkursy i informacje o promocjach książkowych.

Za wadę grup o książkach (por. wykres 6) większość respondentów (63\%) uznała powtarzające się pytania lub posty. 33\% badanych jako minus wskazało także spam pojawiający się w grupach. Krytykowanie gustów i wyborów czytelniczych członków grupy nie podoba się $5 \%$ uczestników tych grup. Z kolei $2 \%$ grupowiczów za wady społeczności grupowych uznała kłótnie o gusty lub wybory książkowe, dyskusje tylko na temat popularnych pozycji oraz niski poziom intelektualny tych dyskusji. 1\% badanych natomiast jako minusy grup podaje: trudność w odnalezieniu szukanych postów, popełnianie błędów ortograficznych w postach, ocenianie grupowiczów na podstawie czytanych pozycji lub wyborów czytelniczych, za dużo autopromocji oraz za małą promocję wydarzeń czytelniczych.
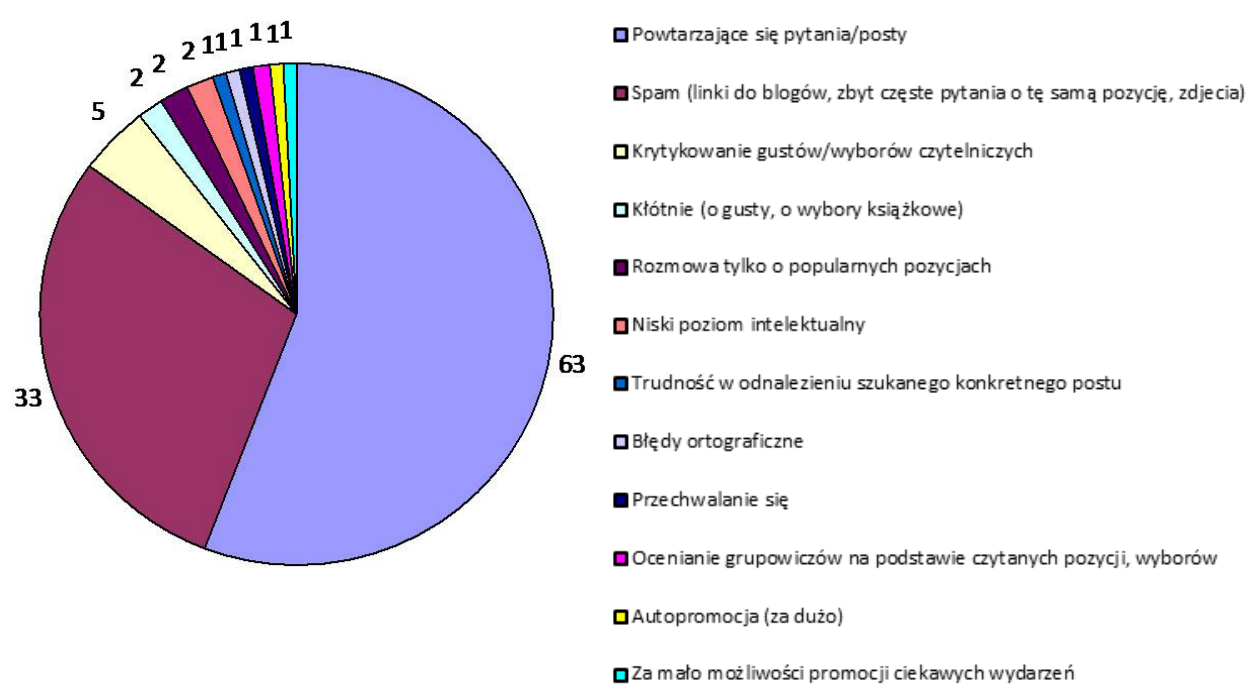

Wykres 6. Wady uczestnictwa w grupach o książkach (udział procentowy)

Źródło: opracowanie własne. 


\section{Podsumowanie}

Grupy poświęcone książkom na Facebooku jako jeden z przykładów e-społeczności integrują miłośników książek. Dają im szerokie możliwości - pozwalają prowadzić dyskusje na tematy literackie, dzielić się nowo poznanymi tytułami i polecać je, a także wydawać opinie. Członkowie grup o książkach są ich w dużej mierze aktywnymi uczestnikami, bardzo chętnie dzielą się swoją pasją z pozostałymi grupowiczami. Wielu z nich to właśnie te powód skłonił, aby zapisać się do grup poświęconych książkom. Jak zaznaczają użytkownicy grup, poprzez te społeczności poznają wiele ciekawych pozycji i poszerzają swoje horyzonty. Grupy o książkach w serwisie Facebook są więc ciekawą propozycją dla wszystkich bibliofilów, którzy chcą dzielić swoją pasję z osobami o takich samych zainteresowaniach. Nie wszystkie jednak, ponieważ większość analizowanych grup ogranicza się tylko do publikowania różnego typu linków - do blogów książkowych, recenzji, konkursów itp. Niekiedy w tym przypadku sugerowanie się samą nazwą grupy może być mylące, np. na grupę o nazwie Dyskusyjny Klub Książki składają się w dużej mierze publikowane linki do innych stron.

Najbardziej interesujące są te grupy, w których pojawia się poza odnośnikami wiele innych informacji - prowadzone są dyskusje na tematy literackie, członkowie podpowiadają sobie nawzajem, czy warto czytać daną pozycję, polecane są ciekawe pozycje lub odbywa się pomoc w poszukiwaniu książek, których tytułu dany czytelnik nie pamięta. Oferty wymiany książkowej, wyzwania czytelnicze, oferty promocji książkowej czy zdjęcia biblioteczek są także ciekawym urozmaiceniem tych społeczności. Do grup najbardziej bogatych w różnego typu ciekawe informacje należą: AK - Klub (nie)anonimowych książkoholików, Nie mam czasu, czytam książki i Z jakiej to książki? Są one idealnym miejscem w Internecie, gdzie miłośnicy książek mogą się spotkać i wymieniać doświadczeniami.

\section{Bibliografia}

Gustowski Wojciech, Komunikacja w mediach społecznościowych, Gdynia 2012. Klepacz Halina, Usielska Anita, Facebook jako konsekwencja ewolucji w komunikacji społecznej, [w:] Media i dziennikarstwo w XX wieku. Studia i szkice, 
pod red. Michała Kaczmarczyka i Magdaleny Boczkowskiej, Sosnowiec 2015, s. 161-174.

Milc Piotr, Media społecznościowe jako forma komunikacji bibliotek z czytelnikiem na przykładzie portalu Facebook, [w:] Bibliotekarz 2.0. Nowe technologie, nowe wyzwania, pod red. Stanisława Skórki, Michała Rogoża, Ewy Piotrowskiej, Kraków 2016, s. 36-46.

Przybysz Janina, Pioterek, Paweł, Media społecznościowe w służbie bibliotek, [w:] Biblioteki bez użytkowników? Diagnoza problemu. V Ogólnopolska Konferencja Naukowa Supraśl 14-16 września 2015, pod red. Jolanty Żochowskiej, Białystok 2015, s. 339-356.

\section{Załącznik nr 1: Grupy facebookowe poświęcone ksiąikom (ankieta 1)}

Metryczka:

1. Płeć:

$$
\begin{aligned}
& \text { kobieta } \\
& \text { mężczyzna }
\end{aligned}
$$

2. Wiek:

$$
\begin{array}{ll}
\square & \text { poniżej 15 lat } \\
\square & 15-19 \text { lat } \\
\square & 20-29 \text { lat } \\
\square & 30-39 \text { lat } \\
\square & 40-49 \text { lat } \\
\square & 50-59 \text { lat } \\
\square & 60 \text { lat i więcej. }
\end{array}
$$

3. Wykształcenie:

$$
\begin{aligned}
& \square \text { podstawowe } \\
& \text { zawodowe } \\
& \square \text { średnie } \\
& \text { wyższe }
\end{aligned}
$$

Pytania:

1. Czy czyta Pan/Pani książki?

tak

nie 
2. Ile książek w ciągu roku Pan/Pani czyta?

3. W jaki sposób znalazł/a Pan/Pani grupę o książkach, do której Pan/Pani należy?

polecił/a mi znajomy/ma

zostałem/łam zaproszony/a przez znajomego/mą

przeglądałem/łam grupy w celu znalezienia grupy, która mi odpowiada

grupa pojawiła się wśród proponowanych grup na Facebooku i dołączyłem/łam do niej

inne. Jakie?

4. Do ilu grup o książkach Pan/Pani należy?

5. Proszę wymienić nazwy kilku grup o książkach, do których Pan/Pani należy?

6. Jakim członkiem grup o książkach jest Pan/Pani?

aktywnym - piszę posty, dodaje zdjęcia, odpowiadam na komentarze itp.

biernym - tylko obserwuję, co dzieje się w grupie, jakie posty się pojawiają

7. Proszę zaznaczyć, czy jest Pan/Pani w jakiś sposób związany/a ze światem książek.
jestem księgarzem
jestem bibliotekarzem
jestem blogerem książkowym
jestem recenzentem książek
jestem wydawcą książek
$\square \quad$ jestem pisarzem
$\square \quad$ jestem czytelnikiem książek
$\square \quad$ inne. Jakie?

8. Co skłoniło Pana/Panią do dołączenia do facebookowych grup poświęconych książkom?

9. Co najbardziej podoba się Panu/Pani w byciu członkiem grup o książkach?

10. Proszę ułożyć od najważniejszych do najmniej ważnych (lub nie występujących w grupie) informacje, jakie uzyskuje Pan/Pani dzięki uczestnictwu w grupach o książkach.

recenzje książek

zdjęcia biblioteczek innych członków grupy

informacje o kiermaszach książek, o tanich książkach

polecanie książek przez innych członków grupy

$\square \quad$ linki do ciekawych pozycji książkowych

zdjęcia fragmentów książek 


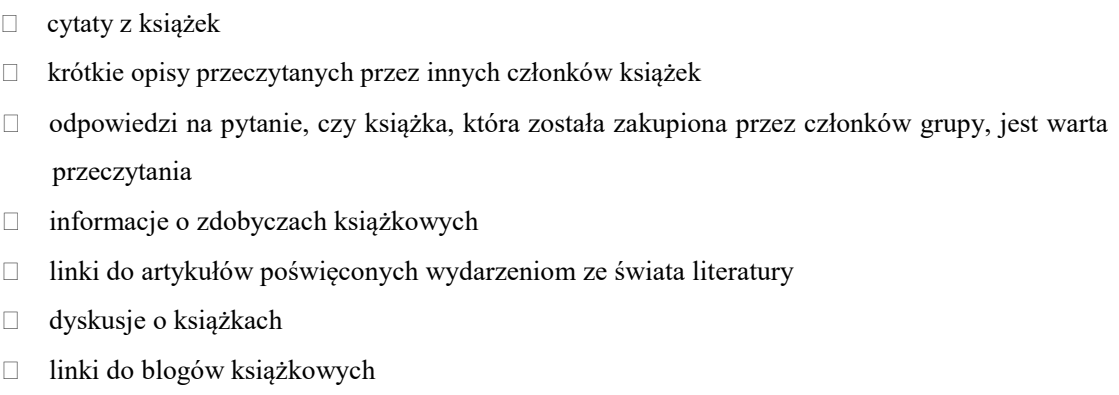

11. Jak długo należy Pan/Pani do facebookowych grup o książkach?.

\section{Załącznik nr 2: Grupy facebookowe poświęcone ksiq̨ỉkom - pytania uzupethiajace (ankieta 2)}

Metryczka:

1. Płeć:
kobieta
mężczyzna

2. Wiek:

$$
\begin{array}{ll}
\square & \text { poniżej 15 lat } \\
\square \quad 15-19 \text { lat } \\
\square \quad 20-29 \text { lat } \\
\square \quad 30-39 \text { lat } \\
\square \quad 40-49 \text { lat } \\
\square \quad 50-59 \text { lat } \\
\square \quad 60 \text { lat i więcej. }
\end{array}
$$

3. Wykształcenie:

$$
\begin{array}{ll}
\square & \text { podstawowe } \\
\square & \text { zawodowe } \\
\square & \text { średnie } \\
\square & \text { wyższe }
\end{array}
$$

Pytania:

1. Czy czyta Pan/Pani książki?

$$
\begin{aligned}
& \square \quad \text { tak } \\
& \square \quad \text { nie }
\end{aligned}
$$

2. Ile książek w ciągu roku Pan/Pani czyta? 
3. Czy zaczął/a Pan/Pani czytać książki dzięki grupie o książkach, do której Pan/Pani należy?

tak

$\square \quad$ nie, czytałem/am już wcześniej

4. Czy zauważył/a Pan/Pani wzrost liczby czytanych książek od momentu przyłączenia się do grup/y o książkach?

tak

$\square$ nie

5. Czy jest Pan/Pani zadowolony/a z wyborów czytelniczych dokonywanych pod wpływem poleceń grupowych?
tak
nie

6. Czy uważa Pan/Pani, że wielu książek nie odkryłby/aby Pan/Pani gdyby nie członkostwo w grupie/ach?
tak
$\square$ nie

7. Czy uważa Pan/Pani, że wielu wydarzeń i inicjatyw związanych z książką nie odkryłby/łaby Pan/Pani gdyby nie członkostwo w grupie/ach?
tak
nie

8. Co nie podoba się Panu/Pani w byciu członkiem grup o książkach?

\section{Bibliophiles Online - A Few Words about Facebook Groups about Books}

ABSTRACT: Internet offers new opportunities of communication and integration for book lovers - giving them the possibility to create a community focused on their main passion - reading. The article characterizes a specific type of these communities - Facebook groups about books. The definition of social media and e-communities was presented. Facebook web site was described and characterized. It was noted that the Internet, and therefore Facebook, is a place where lovers of the written word have the ability to communicate between themselves and to integrate. Then, the article presents one of the ways of communication among book lovers on Facebook - book groups. Based on the 
analysis of 47 groups, the article try to present its structure (size, access and activity of participants) and study the information published by their members. It was pointed out which of these information is most relevant to their participants. The members of the book groups were characterized as well, based on the surveys conducted between them. It has been shown, which elements are the most appreciated by their participants and which they consider the biggest flaws, finally what encouraged them to join the communities.

KEYWORDS: book, group, e-societies, Facebook, Internet, social media. 